\title{
$\beta$-Mannanase Production Using Coffee Industry Waste for Application in Soluble Coffee Processing
}

\author{
Camila P. Favaro ${ }^{1,2}$, Ilton J. Baraldi ${ }^{3}{ }^{(\mathbb{C}}$, Fernanda P. Casciatori ${ }^{2}\left(\mathbb{D}\right.$ and Cristiane S. Farinas ${ }^{1,2, *}$ \\ 1 Embrapa Instrumentation, Rua XV de Novembro 1452, São Carlos, SP 13560-970, Brazil; \\ camilapfavaro@yahoo.com.br \\ 2 Graduate Program in Chemical Engineering, Federal University of São Carlos, São Carlos, \\ SP 13565-905, Brazil; fernanda.casciatori@ufscar.br \\ 3 Department of Food Engineering, Federal University of Technology of Paraná, Medianeira, \\ PR 85884-000, Brazil; baraldi@utfpr.edu.br \\ * Correspondence: cristiane.farinas@embrapa.br; Tel.: +55-16-2107-2908; Fax: +55-16-2107-2902
}

Received: 2 January 2020; Accepted: 30 January 2020; Published: 4 February 2020

\begin{abstract}
Soluble coffee offers the combined benefits of high added value and practicality for its consumers. The hydrolysis of coffee polysaccharides by the biochemical route, using enzymes, is an eco-friendly and sustainable way to improve the quality of this product, while contributing to the implementation of industrial processes that have lower energy requirements and can reduce environmental impacts. This work describes the production of hydrolytic enzymes by solid-state fermentation (SSF), cultivating filamentous fungi on waste from the coffee industry, followed by their application in the hydrolysis of waste coffee polysaccharides from soluble coffee processing. Different substrate compositions were studied, an ideal microorganism was selected, and the fermentation conditions were optimized. Cultivations for enzymes production were carried out in flasks and in a packed-bed bioreactor. Higher enzyme yield was achieved in the bioreactor, due to better aeration of the substrate. The best $\beta$-mannanase production results were found for a substrate composed of a mixture of coffee waste and wheat bran (1:1 w/w), using Aspergillus niger F12. The enzymatic extract proved to be very stable for $24 \mathrm{~h}$, at $50^{\circ} \mathrm{C}$, and was able to hydrolyze a considerable amount of the carbohydrates in the coffee. The addition of a commercial cellulase cocktail to the crude extract increased the hydrolysis yield by $56 \%$. The production of $\beta$-mannanase by SSF and its application in the hydrolysis of coffee polysaccharides showed promise for improving soluble coffee processing, offering an attractive way to assist in closing the loops in the coffee industry and creating a circular economy.
\end{abstract}

Keywords: bioprocess engineering; coffee carbohydrates; enzymatic hydrolysis; agro-industrial residues; solid-state fermentation (SSF); column bioreactor

\section{Introduction}

Coffee is widely produced and consumed globally. Brazil is the largest producer, followed by Vietnam and Colombia, with these three countries being responsible for more than half of the total supply of coffee. World coffee production in 2019/20 is projected to be 167 million bags, comprising 95 million bags of Arabica and 72 million bags of Robusta, while world coffee demand is projected to be 168 million bags. The use of instant coffee has increased, due to its advantages in terms of practicality, ease of preparation, and reduced wastage. Exports of soluble coffee have more than doubled over the last two decades, but remain small in volume terms, since over $90 \%$ of coffee is exported in the green form. Hence, most of the addition of value in the coffee industry occurs in the importing countries. In addition to market issues, many technical challenges still need to be overcome in order to expand the soluble coffee industry, especially in coffee producing countries [1]. 
For good soluble coffee productivity, a high yield is required in the extraction of the coffee polysaccharides, since water-soluble polysaccharides are the main components of the coffee extract. These polysaccharides are important for retaining volatile compounds and for providing the desired viscosity, ensuring satisfactory quality of the beverage [2]. The spent coffee grounds are rich in non-solubilized polysaccharides such as galactomannans, arabinogalactans, and cellulose, with half of the total being in the form of galactomannans [3-5]. Currently, thermal hydrolysis processes are used industrially to increase the extraction of polysaccharides, but these processes have high energy consumption and generate undesirable compounds that negatively impact the taste of the beverage [6]. A more eco-friendly and sustainable potential strategy for the hydrolysis and solubilization of coffee polysaccharides is to use an enzymatic route, since enzymes act under moderate process conditions and are highly specific. The main enzymes involved in degradation of the mannan structures are $\beta$-mannanase, $\beta$-mannosidase, $\beta$-glycosidase, and $\alpha$-galactosidase [7]. Mannanases can be produced by a wide range of microorganisms, including different fungi [8-11] and bacteria [12-14].

Given the high costs of commercial enzymes, solid-state fermentation (SSF) can be an advantageous option that offers higher productivity of the enzymatic extracts, less susceptibility to inhibition, and greater stability of the enzymes towards variations of temperature and $\mathrm{pH}$ [15-17]. In SSF, microorganisms are cultivated on moist solid substrates, where the interparticle spaces are filled with air. Filamentous fungi adapt well to the low water activities of SSF systems, usually secreting enzymes into the extracellular medium during the growth phase. The benefits of using SSF for enzymes production are two-fold: the enzymes produced are of high economic value and they can be used in many different areas, including in the food industry [18].

The production of enzymes in SSF can be affected by culture conditions such as temperature, moisture content of the solid porous medium, $\mathrm{pH}$ of the solution impregnated into the particles, porosity of the substrate bed, aeration conditions, oxygen transfer, and the substrate type and composition. The residues generated in the coffee industry are potential substrates for the production of $\beta$-mannanases [19], since the enzymes produced using such a substrate should be more specific for degradation of this material. In addition, given the very large amounts of coffee residues produced worldwide, the reuse of this material could contribute to the development of industrial processes that have lower environmental and energy impacts. Recently, the production of cellulase enzymes by SSF using coffee husk as substrate has been demonstrated [20], thus showing the potential of this strategy. However, despite the wide range of biotechnological applications to valorize the spent coffee grounds residue [21-23], such as biogas and fertilizer production, its use as substrate for enzyme production still needs to be further investigated.

Considering the above issues, this work evaluates the use of agro-industrial coffee waste to produce hydrolytic enzymes by SSF, focusing on the production of $\beta$-mannanase. Different fungi were tested, as well as combinations of the coffee waste with other substrates. The best operational conditions were defined at the flask scale, as well as using a column bioreactor. Fungal growth was correlated with enzymes production and the crude enzymatic extracts were applied in the hydrolysis of the coffee polysaccharides, in order to evaluate the ability of these enzymes to solubilize them, with the aim of improving soluble coffee processing, using an eco-friendly and sustainable strategy.

\section{Materials and Methods}

\subsection{Substrate}

The medium roast Arabica coffee was obtained from Café Kühl (Limeira, São Paulo State, Brazil). The coffee residue was prepared by grinding the roasted coffee beans in a knife mill fitted with a 2-4 $\mathrm{mm}$ sieve. Extraction was performed with boiling water for $15 \mathrm{~min}$, using a water:coffee ratio of 6:1 $(\mathrm{v} / \mathrm{w})$. The extract was filtered and the spent coffee was dried at $60^{\circ} \mathrm{C}$ in an oven with air circulation, until reaching 3-5\% moisture content. This residue was then sieved and separated into 1-2 $\mathrm{mm}$ particles for storage and subsequent use in the SSF and hydrolysis experiments. Wheat bran (obtained in São 
Carlos, São Paulo State, Brazil) and sugarcane bagasse (obtained in Piracicaba, São Paulo State, Brazil) were sieved, with particles $>1 \mathrm{~mm}$ and 1-2 $\mathrm{mm}$, respectively, being used in the SSF experiments.

\subsection{Microorganisms}

The fungal strains Aspergillus niger F12, Aspergillus niger 3T5B8, Aspergillus niger C, Aspergillus awamori 108(4), Aspergillus oryzae P6B8, Trichoderma reesei, and Trichoderma harzianum were used in this study. These fungal strains were obtained from the Embrapa Food Technology Collection (Rio de Janeiro, Brazil), except for the A. awamori 108(4) strain, which was provided by the Laboratory of Microbiology and Biomolecules (Center of Biological Sciences and Health, Federal University of São Carlos, São Carlos, Brazil). The stock culture was grown on a potato dextrose agar (PDA) medium, at $32{ }^{\circ} \mathrm{C}$, until sporulation. A spore suspension was prepared in sterile Tween $80(0.3 \%, v / v)$, for each slant culture. The spore concentrations in the suspensions were determined by counting in a Neubauer chamber.

\subsection{Solid-State Fermentation in Flasks}

A mixture of coffee residue and wheat bran $(1: 1, w / w)$ was first used as the solid substrate. The initial moisture content was adjusted to 50\% (v/w) with Mandels medium [24], and the initial $\mathrm{pH}$ value was adjusted to 5.5. SSF was carried out in $250 \mathrm{~mL}$ Erlenmeyer flasks. After sterilization at $121{ }^{\circ} \mathrm{C}$ for $20 \mathrm{~min}$ in an autoclave, the culture medium was inoculated with $10^{7}$ spores per gram of substrate. The inoculated medium was incubated at $30^{\circ} \mathrm{C}$ for $120 \mathrm{~h}$. After the cultivation period, the enzymes were extracted by adding $50 \mathrm{~mL}$ of $0.05 \mathrm{M}$ sodium citrate buffer ( $\mathrm{pH}$ 5.3) to each $10 \mathrm{~g}$ of substrate and shaking (at $200 \mathrm{rpm}$ ) for $30 \mathrm{~min}$ at $30^{\circ} \mathrm{C}$. The liquid was filtered and subjected to centrifugation at $4{ }^{\circ} \mathrm{C}, 10,000 \mathrm{rpm}$, for $15 \mathrm{~min}$. The clarified extract was stored at $-18^{\circ} \mathrm{C}$ prior to the analyses. Three biological replications were carried out for each test. The best fungal strain could then be selected from these experiments.

Following the same experimental procedure, using the chosen fungal strain, the composition of the substrate was varied, using coffee waste alone (CW), CW combined (1:1, w/w) with wheat bran (WB), and $C W$ combined $(1: 1, w / w)$ with sugarcane bagasse (SB). Once CW combined with WB had been selected as the substrate, the $\mathrm{CW}: \mathrm{WB}$ ratio was also varied, aiming to maximize $\beta$-mannanase activity. The results for substrate selection were subjected to Duncan's multiple range tests, at a significance level of $p<0.05$.

\subsection{Solid-State Fermentation in a Column-Type Bioreactor}

SSF cultivations were carried out in a column-type packed-bed bioreactor containing a previously inoculated medium, placed in a temperature-controlled water bath. The bioreactor system, consisting of so-called Raimbault columns, was composed of small glass columns (220 mm high, $24 \mathrm{~mm}$ outside diameter, and $20 \mathrm{~mm}$ internal diameter) within which the substrate was packed. Aeration of each column was achieved by percolating air (relative humidity of $80 \%$ at the inlet) through the bed of substrate, at a flow rate of $20 \mathrm{~mL} / \mathrm{min}$. The small quantity of medium packed within each column (a few grams) and the geometric characteristics of the glass columns make these bioreactors suitable for maintaining the ideal process temperature (since there is sufficient removal of heat through the wall) [25]. The cultivation conditions were $30{ }^{\circ} \mathrm{C}, 50 \%$ initial moisture content, and initial pH 5.0, with A. niger F12 growing in a mixture of coffee waste and wheat bran $(1: 1, w / w)$, for comparison with the SSF assays in flasks.

An addional set of cultivations in the column-type packed-bed bioreactor was carried out using a factorial design to evaluate the effects of temperature $\left(X_{1}\right)$, initial $\mathrm{pH}\left(\mathrm{X}_{2}\right)$, and initial substrate moisture content $\left(X_{3}\right)$ on the production yields of $\beta$-mannanase and $\beta$-glycosidase. The experimental design selected was a $2^{3}$ factorial design comprising eleven runs, corresponding to eight axial points and three central points, with the experiments carried out in random order. Each assay was performed in triplicate. The results of the factorial design assays were treated using STATISTICA 8.0 software 
(StatSoft, Inc., 2007). The selected conditions found in this factorial design was used to carry out the respirometric analyses by measuring $\mathrm{CO}_{2}$ in the outlet air stream leaving the columns of the bioreactor system, using a GMM 220 instrument (Vaisala, Vantaa, Finland). The cumulative amount of $\mathrm{CO}_{2}$ produced was calculated from the area under the $\mathrm{CO}_{2}$ vs. cultivation time curve.

\subsection{Effect of Temperature and $p H$ on $\beta$-Mannanase Activity}

Cultivation experiments for the production of enzymes were performed in the column-type bioreactor at the selected conditions of $32^{\circ} \mathrm{C}$, initial pH 6.0, and addition of $8 \mathrm{~mL}$ of Mandels medium [24] to provide the desired moisture content for each $10 \mathrm{~g}$ of substrate composed of coffee waste and wheat bran $(1: 1, w / w)$. A central composite rotatable design (CCRD) was used to evaluate the effects on the enzymatic activity of two variables (temperature and $\mathrm{pH}$ ) and their possible interaction. The experimental design selected was a central composite design comprising eleven runs, corresponding to four cube points, four axial points, and three central points, with the experiments carried out in random order. The dependent (response) variable was the $\beta$-mannanase activity. STATISTICA 8.0 software was used to analyze the experimental data, as well as to generate the ANOVA (analysis of variance) data and to plot the response surface. The assays were conducted using different $\mathrm{pH}$ values of the $50 \mathrm{mM}$ sodium citrate buffer. The enzymatic activities were measured at different temperatures, adjusted using a temperature-controlled water bath. The substrate used was $0.5 \%(w / v)$ locust bean, prepared at the different buffer $\mathrm{pHs}$, and the hydrolysis time was $20 \mathrm{~min}$. A second order polynomial model of the form shown in Equation (1) was used to fit the data:

$$
Y=\beta_{0}+\beta_{1} \cdot X_{1}+\beta_{2} \cdot X_{2}+\beta_{11} \cdot X_{1}^{2}+\beta_{22} \cdot X_{2}^{2}+\beta_{12} \cdot X_{1} \cdot X_{2}
$$

where $\mathrm{Y}$ is the predicted response for $\beta$-mannanase activity, expressed as $\mathrm{IU} / \mathrm{g} ; \beta_{0}$ is the intercept term; $\beta_{1}$ and $\beta_{2}$ are the linear coefficients; $\beta_{11}$ and $\beta_{22}$ are the square coefficients; $\beta_{12}$ is the interaction coefficient; and $X_{1}$ and $X_{2}$ are the coded independent variables (temperature and $\mathrm{pH}$, respectively). The terms that were not statistically significant were removed from the model and added to the lack of fit. The thermostability of $\beta$-mannanase was evaluated during $24 \mathrm{~h}$ at $50,60,70$, and $80{ }^{\circ} \mathrm{C}$.

\subsection{Enzymatic Hydrolysis of Coffee Residue}

The experiments were carried out in $5 \mathrm{~mL}$ tubes, using a loading of 5,10 , and $20 \%$ solids and $4 \mathrm{~mL}$ of crude enzyme extract. The enzymatic extract was produced by cultivation at $32{ }^{\circ} \mathrm{C}$, with an initial $\mathrm{pH}$ of 6.0 and addition of $8 \mathrm{~mL}$ of Mandels medium to provide the desired moisture content for each $10 \mathrm{~g}$ of substrate composed of coffee waste and wheat bran $(1: 1, w / w)$. When using the commercial Cellic CTec3 enzyme cocktail (Novozymes, Araucária, PR, Brazil), a sufficient quantity of the powder was diluted in $4 \mathrm{~mL}$ of $0.05 \mathrm{M}$ sodium citrate buffer ( $\mathrm{pH}$ 5.3) to provide 2-5 FPU/g of coffee residue. Control of the hydrolysis $\mathrm{pH}$ was performed with the addition of $4 \mathrm{~mL}$ of $0.05 \mathrm{M}$ sodium citrate buffer ( $\mathrm{pH}$ 5.3). The supernatant was separated using two centrifugations, in Eppendorf tubes, for $10 \mathrm{~min}$ at $12,000 \mathrm{rpm}$ and $4{ }^{\circ} \mathrm{C}$. The progress of the hydrolysis was followed using the DNS method [26] to determine the reducing sugars released. The experiments and analyses were performed in triplicate.

\subsection{Analytical Methods}

The $\beta$-mannanase activity was determined by mixing $0.1 \mathrm{~mL}$ of an appropriately diluted enzyme sample with $0.9 \mathrm{~mL}$ of $0.5 \%(w / v)$ locust bean gum (Sigma G-0753) in $0.05 \mathrm{M}$ sodium citrate buffer ( $\mathrm{pH}$ 5.3), followed by heating at $50{ }^{\circ} \mathrm{C}$ for $20 \mathrm{~min}$ [27]. The reducing sugar released (as mannose) was determined by the dinitrosalicylic acid (DNS) method [26]. The activity was expressed in IU/g, corresponding to $1.0 \mu \mathrm{mol}$ of reducing sugar released as mannose or glucose per minute and per $g$ of solid that provided a given volume of enzymatic extract. The $\beta$-glucosidase activities were determined using a substrate of $150 \mathrm{mM}$ cellobiose solution (Sigma, Saint Loius, MO, USA), prepared in $0.05 \mathrm{M}$ sodium citrate buffer ( $\mathrm{pH}$ 4.8) [28]. The reaction was carried out by incubating the enzyme:substrate 
(ratio of $1: 1, v / v$ ) solution for $30 \mathrm{~min}$ at $50^{\circ} \mathrm{C}$. The reaction was stopped by submersion in boiling water for $5 \mathrm{~min}$. The glucose released was determined using a GOD-POD glucose test kit (Labtest, Lagoa Santa, MG, Brazil), following the procedure recommended by the manufacturer.

\section{Results and Discussion}

\subsection{Effect of Substrate on Production of $\beta$-Mannanase}

In the solid-state fermentations, evaluation was made of the use of coffee waste $(\mathrm{CW})$ as the sole solid substrate, as well as in combination with wheat bran (WB) or sugarcane bagasse (SB), for the production of $\beta$-mannanase and $\beta$-glycosidase. The most appropriate solid substrate was considered to be the one that provided the highest production of these enzymes. Table 1 presents the enzymatic activities obtained for cultivation of $A$. niger F12 under SSF in flasks, at different times (72, 96, and $120 \mathrm{~h}$ ), for all the solid substrates.

Table 1. Enzymatic activities of $\beta$-mannanase and $\beta$-glycosidase obtained for SSF with A. niger F12 at $30{ }^{\circ} \mathrm{C}, \mathrm{pH} 5.0$, and $50 \%(v / w)$ moisture content, using different solid substrates.

\begin{tabular}{ccccc}
\hline \multirow{2}{*}{ Enzyme } & Time (h) & \multicolumn{3}{c}{ Enzymatic Activity (IU/g) * } \\
\cline { 3 - 5 } & & SB + CW & CW & WB + CW \\
\hline \multirow{3}{*}{$\beta$-mannanase } & 92 & $7.33 \pm 0.44 \mathrm{c}$ & $10.16 \pm 0.65 \mathrm{~b}$ & $34.91 \pm 0.75 \mathrm{a}$ \\
& 120 & $5.75 \pm 0.84 \mathrm{c}$ & $15.42 \pm 0.32 \mathrm{~b}$ & $44.05 \pm 0.85 \mathrm{a}$ \\
& 72 & $45.36 \pm 1.15 \mathrm{~b}$ & $2.12 \pm 0.08 \mathrm{c}$ & $67.54 \pm 2.29 \mathrm{a}$ \\
$\beta$-glucosidase & 96 & $51.80 \pm 0.07 \mathrm{~b}$ & $2.66 \pm 0.26 \mathrm{c}$ & $69.85 \pm 2.40 \mathrm{a}$ \\
& 120 & $47.93 \pm 0.42 \mathrm{~b}$ & $3.03 \pm 0.05 \mathrm{c}$ & $72.54 \pm 2.70 \mathrm{a}$ \\
\hline
\end{tabular}

* Mean \pm standard error; SB: sugarcane bagasse; CW: coffee waste; WB: wheat bran. Different letters in the same line indicate significant differences (Duncan's test, $p \leq 0.05)$. The ratios of SB $+\mathrm{CW}$ and WB $+\mathrm{CW}$ were $(1: 1, w / w)$.

The use of a mixture of coffee waste and wheat bran as solid substrate during the SSF using A. niger F12 resulted in higher activities for both $\beta$-mannanase and $\beta$-glycosidase (Table 1 ). Wheat bran is considered a suitable waste for fermentation processes [29], with excellent industrial potential due to its high water retention capacity [30], good heat dissipation, and air circulation between the particles, allowing effective penetration of the fungal mycelium. It is also a complex substrate, acting as a source of carbon and nitrogen, in addition to being inexpensive [31,32]. These characteristics were observed in this work, since the wheat bran provided the fungus with an ideal environment for its growth, while the coffee waste served as an inducer for $\beta$-mannanase production, due to its high content of galactomannans.

In order to further evaluate the use of a combination of coffee waste and wheat bran as substrate for enzyme production, different ratios of these substrates were used during SSF (Figure 1). The ratio of coffee waste to wheat bran in the medium had a crucial effect on fungal growth and $\beta$-mannanase production. The data presented in Figure 1 show that the $\beta$-mannanase activity increased as the ratio of CW to WB increased, with the highest value reached at a ratio of 1:1 (w/w), followed by a decrease as the ratio was increased further. The statistical model identified the point of maximum enzymatic activity at a 1:1 ratio of coffee waste and wheat bran $\left(\mathrm{R}^{2}=0.84\right)$, with small variations between ratios of 2:3 and 3:2 not affecting the enzyme production. Therefore, the 1:1 $(w / w)$ ratio was chosen as the optimum for enzyme production in the subsequent experiments. These results indicate that the coffee residue is important to favor the production of $\beta$-mannanase, while the wheat bran acted as a nutrient source, providing the physical and chemical characteristics necessary for growth of the microorganism. 


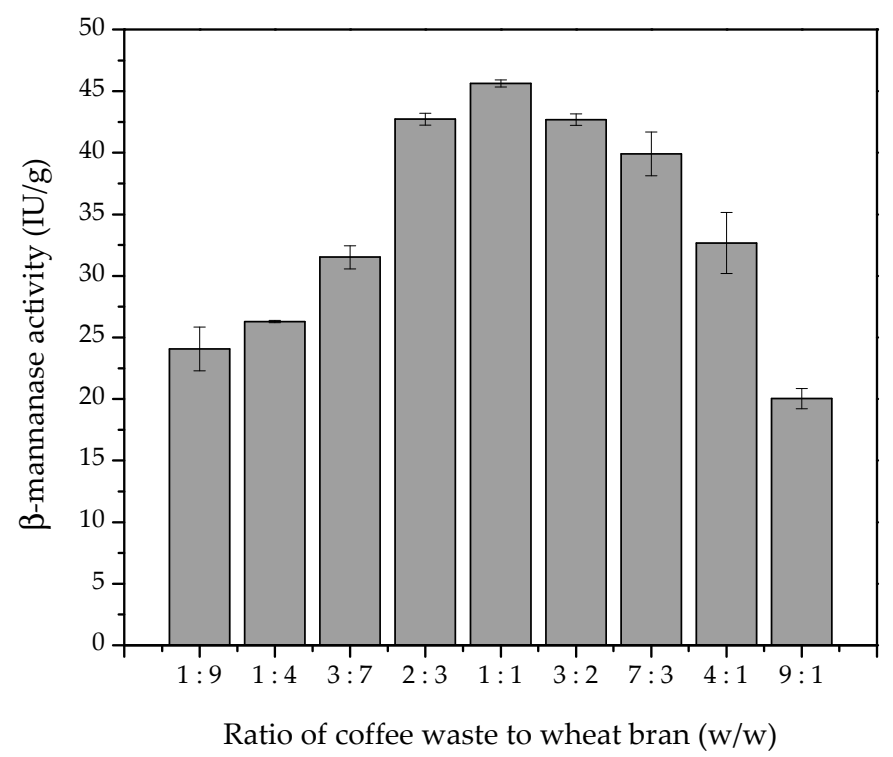

Figure 1. Effect of the ratio of coffee waste to wheat bran on the production of $\beta$-mannanase by A. niger F12 under SSF, at an initial moisture content of $50 \%(v / w), \mathrm{pH} 5.0$, and $30{ }^{\circ} \mathrm{C}$.

\subsection{Effect of Different Fungi on Enzyme Production}

Different filamentous fungi were studied for the production of $\beta$-mannanase under SSF, using the combination of coffee waste and wheat bran $(1: 1, w / v)$ as solid substrate. Figure 2 shows the specific activity of $\beta$-mannanase produced by each fungus, after $120 \mathrm{~h}$ of cultivation. The highest production of $\beta$-mannanase was obtained using A. niger F12, followed by A. niger 3T5B8.

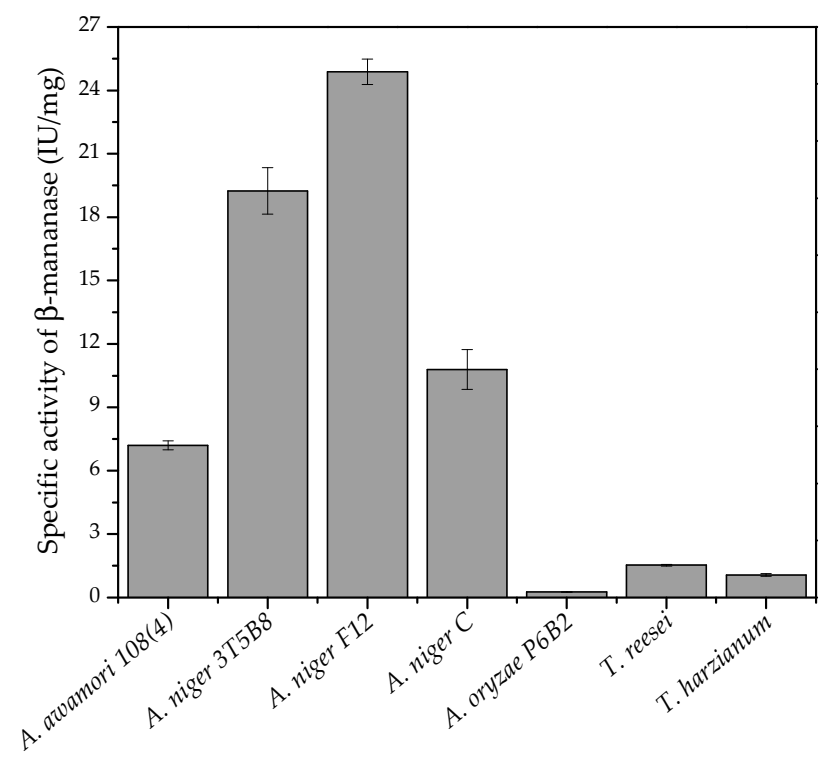

Figure 2. Specific activities of $\beta$-mannanase after SSF with different fungi for $120 \mathrm{~h}$ at $30{ }^{\circ} \mathrm{C}, \mathrm{pH} 5.0$, and $50 \%(v / w)$ moisture content.

According to De Vries and Visser [33], strains of Aspergillus ssp. are the most important decomposers of hemicelluloses and celluloses in nature, having the capacity to produce several enzymes that degrade plant cell wall components. Ferreira and Filho [34] evaluated the production of $\beta$-mannanase by submerged fermentation using T. harzianum $\mathrm{T} 4$ and observed that the enzyme started to be produced on the sixth day of cultivation, reaching a peak on the eighth day, with activity of approximately $9 \mathrm{IU} / \mathrm{mL}$. In the present work, $\beta$-mannanase production by $A$. niger $\mathrm{F} 12$ reached 8.6 
$\mathrm{IU} / \mathrm{mL}$ in five days, indicating better productivity of the enzyme under solid-state cultivation and with the use of this fungus.

\subsection{Comparison of the Types of Cultivation Under SSF}

The main advantage of SSF is the ability to use raw materials from agroindustry waste, but this technology has some drawbacks related to scale-up and the extraction of desired products in the downstream steps [35]. At the laboratory scale, flasks are usually used. In this case, the process occurs without forced aeration, is low cost, and is easy to handle, but it is difficult to control the operational parameters. The packed-bed bioreactor with glass columns (the Raimbault system) is provided with forced aeration through the static bed of particles, which helps to replenish $\mathrm{O}_{2}$ and water, while at the same time avoiding the accumulation of heat and $\mathrm{CO}_{2}$. In this work, both cultivation systems were evaluated. Table 2 shows the $\beta$-mannanase and $\beta$-glucosidase productivities obtained using flasks and the SSF column bioreactor. The $\beta$-mannanase activity on the third day of cultivation in the column bioreactor $(52.6 \pm 1.6 \mathrm{IU} / \mathrm{g})$ was statistically equal to the activity achieved on the fifth day of cultivation in the Erlenmeyer flasks $(51.9 \pm 0.7 \mathrm{IU} / \mathrm{g})$. The production of $\beta$-glucosidase was also higher using the column bioreactor. For both enzymes, cultivation in the bioreactor resulted in the highest productivity values after $72 \mathrm{~h}$ of cultivation. For $\beta$-mannanase, the productivity after $72 \mathrm{~h}$ was $50.7 \%$ higher when the bioreactor was used, rather than the flasks. Therefore, the results obtained for SSF in the bioreactor were promising, since there were higher production and productivity values for both enzymes, achieved in a shorter cultivation time, which would be favorable for improving the economic feasibility of the process.

Table 2. Productivities of $\beta$-mannanase and $\beta$-glucosidase obtained in different types of cultures using A. niger $\mathrm{F} 12$ at $30^{\circ} \mathrm{C}$, $\mathrm{pH} 5.0,50 \%$ moisture content, and 1:1 (w/w) coffee waste:wheat bran.

\begin{tabular}{ccccc}
\hline \multirow{2}{*}{ Time (h) } & \multicolumn{4}{c}{ Productivity (IU/g.h) * } \\
\cline { 2 - 5 } & \multicolumn{2}{c}{ Erlenmeyer Flasks } & \multicolumn{2}{c}{ Column Bioreactor } \\
\cline { 2 - 5 } & $\beta$-Mannanase & $\beta$-Glucosidase & $\beta$-Mannanase & $\beta$-Glucosidase \\
\hline 72 & $0.48 \pm 0.01$ & $0.94 \pm 0.03$ & $0.73 \pm 0.02$ & $1.00 \pm 0.03$ \\
96 & $0.46 \pm<0.01$ & $0.73 \pm 0.02$ & $0.62 \pm<0.01$ & $0.82 \pm 0.04$ \\
120 & $0.43 \pm<0.01$ & $0.60 \pm 0.02$ & $0.49 \pm 0.05$ & $0.66 \pm 0.03$ \\
\hline
\end{tabular}

* Mean \pm standard error.

Cerda et al. [20] used a solid-state fermentation bioreactor for the production of cellulase and xylanase, using coffee husks combined with other non-sterile residues as substrates. It was observed that the microorganisms acted synergistically in the production of the enzymes, with low gaseous emissions and reduced energy requirements making the bioprocess more environmentally friendly. García et al. [36] cultivated Penicillium purpurogenum in plastic bags, using coffee husks and coffee pulp as substrates, with the addition of sterilized cheese whey as a supplementary source of fermentable sugars (4.5-5.0\% lactose), aiming at the extraction of total phenolic compounds. The coffee industry wastes supplemented with cheese whey were appropriate substrates for the growth of the microorganism and for obtaining phenolic compounds by the action of the enzymes produced during the process. In agreement with the earlier studies, the present findings showed that it was possible to create an environment that provided sufficient nutrients for both fungal growth and production of the desired enzymes.

\subsection{Optimization of $\beta$-Mannanase and $\beta$-Glucosidase Production in Bioreactor Fermentation}

The important SSF variables analyzed for the optimization of enzymes production were temperature, initial $\mathrm{pH}$, and initial moisture content. Table 3 presents the matrix of the assays, showing the real and coded values, together with the means and standard errors for the activities of 
$\beta$-mannanase and $\beta$-glucosidase (IU/g), determined in triplicate. The highest activities of the enzymes were found for the central point condition.

Table 3. Factorial $2^{3}$ design for the production of enzymes (IU/g) in $72 \mathrm{~h}$ of SSF with $A$. niger F12 and 1:1 $(w / w)$ coffee waste:wheat bran under different conditions of temperature, $\mathrm{pH}$ and initial moisture content.

\begin{tabular}{cccccc}
\hline Run & $\mathbf{X}_{\mathbf{1}}{ }^{\mathbf{a}}$ & $\mathbf{X}_{\mathbf{2}}{ }^{\mathbf{b}}$ & $\mathbf{X}_{\mathbf{3}}{ }^{\mathbf{c}}$ & $\boldsymbol{\beta}$-Mannanase (IU/g) ${ }^{*}$ & $\beta$-Glucosidase (IU/g) \\
\hline 1 & $-1(29)$ & $-1(5)$ & $-1(5.6)$ & $37.31 \pm 0.46$ & $35.58 \pm 2.06$ \\
2 & $+1(35)$ & $-1(5)$ & $-1(5.6)$ & $39.26 \pm 3.71$ & $32.92 \pm 0.91$ \\
3 & $-1(29)$ & $+1(7)$ & $-1(5.6)$ & $35.96 \pm 0.47$ & $40.01 \pm 0.61$ \\
4 & $+1(35)$ & $+1(7)$ & $-1(5.6)$ & $44.71 \pm 2.19$ & $33.65 \pm 2.12$ \\
5 & $-1(29)$ & $-1(5)$ & $+1(10.4)$ & $35.14 \pm 1.03$ & $29.87 \pm 2.01$ \\
6 & $+1(35)$ & $-1(5)$ & $+1(10.4)$ & $42.62 \pm 2.03$ & $34.62 \pm 0.98$ \\
7 & $-1(29)$ & $+1(7)$ & $+1(10.4)$ & $37.91 \pm 2.00$ & $36.29 \pm 1.72$ \\
8 & $+1(35)$ & $+1(7)$ & $+1(10.4)$ & $49.65 \pm 0.83$ & $36.09 \pm 1.67$ \\
9 & $0(32)$ & $0(6)$ & $0(8)$ & $59.03 \pm 2.30$ & $43.10 \pm 1.60$ \\
10 & $0(32)$ & $0(6)$ & $0(8)$ & $62.40 \pm 2.30$ & $43.62 \pm 1.39$ \\
11 & $0(32)$ & $0(6)$ & $0(8)$ & $63.50 \pm 2.97$ & $41.77 \pm 1.80$ \\
\hline
\end{tabular}

* Mean \pm standard error; ${ }^{\text {a }} \mathrm{X}_{1}$ : temperature $\left({ }^{\circ} \mathrm{C}\right) ;{ }^{b} \mathrm{X}_{2}: \mathrm{pH} ;{ }^{\mathrm{c}} \mathrm{X}_{3}$ : initial moisture content (the uncoded values within parentheses are the volumes of solution added to $10 \mathrm{~g}$ of solid substrate).

Considering the effects of the significant variables (99\% confidence level), the largest and most significant effect was the curvature effect. This indicated that the production of these enzymes was optimized at the levels of the central point (tests 9, 10, and 11 in Table 3).

Therefore, the experimental conditions of the central point were selected to produce the enzymatic extract to be characterized in terms of thermostability and the optimal conditions of $\mathrm{pH}$ and temperature for enzymatic activity. This extract was also used in the hydrolysis of the coffee polysaccharides. The optimum temperature for enzymes production by fermentation is usually close to the ideal temperature for growth of the microorganism, especially when the enzymes are products associated with growth, as in the case of the $\beta$-mannanase and $\beta$-glucosidase investigated here.

\subsection{Time Profile of $\beta$-Mannanase Production}

In SSF, the microbial biomass grows entangled in the solid substrate, which makes direct measurement of the microbial biomass concentration almost impossible. An indirect way to estimate fungal growth in SSF is by monitoring the behavior of respiratory gases (either the oxygen consumed or the $\mathrm{CO}_{2}$ produced by metabolism) [37]. A comparison of the $\beta$-mannanase produced and the $\mathrm{CO}_{2}$ accumulated during cultivation of $A$. niger F12 using an inlet air relative humidity of $80 \%$ and an air flow rate of $20 \mathrm{~mL} / \mathrm{min}$ is presented in Figure 3.

The total amount of $\mathrm{CO}_{2}$ produced showed a good correlation with $\beta$-mannanase production $\left(R^{2}=0.963\right)$, especially after the first $24 \mathrm{~h}$ of cultivation. These results evidenced that the production of carbon dioxide during the cultivation period could provide valuable information about the progress of enzyme production. 


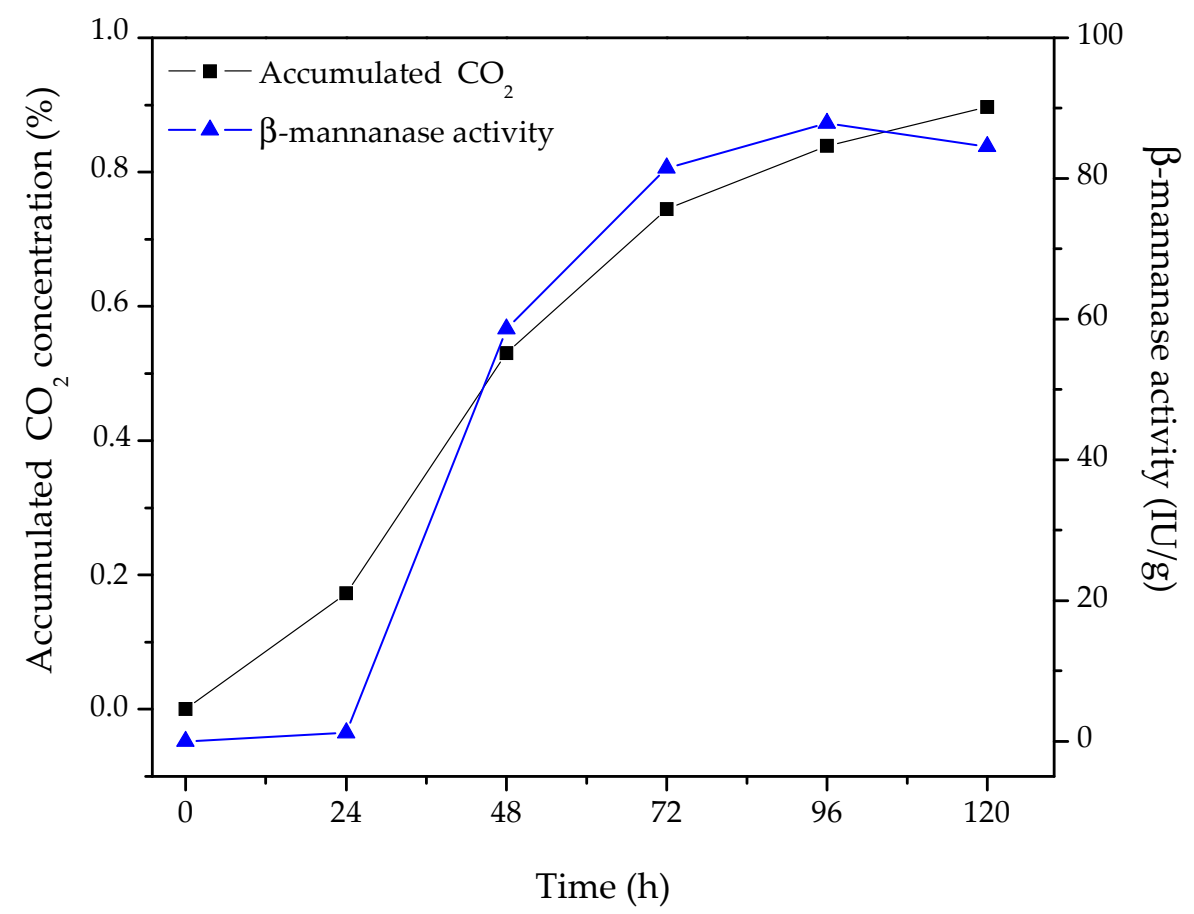

(a)

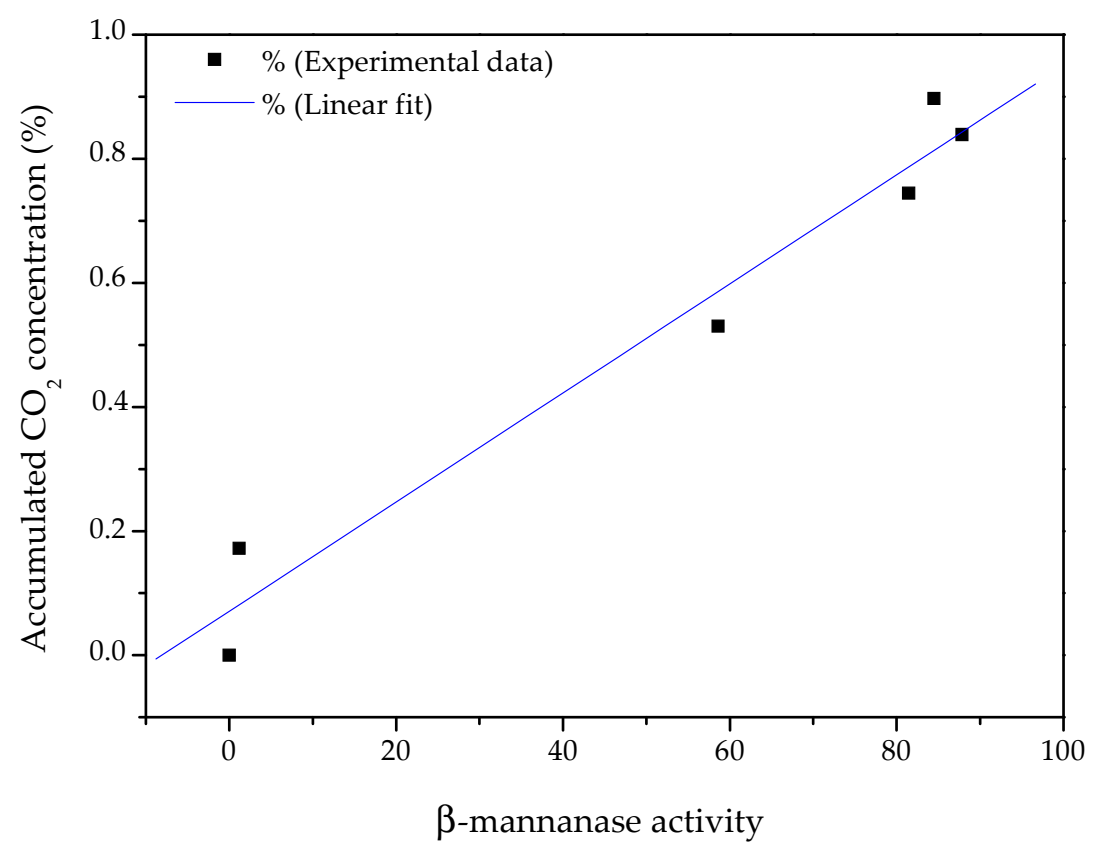

(b)

Figure 3. Cont. 




Time (h)

(c)

Figure 3. SSF for $120 \mathrm{~h}$ in the column bioreactor with A. niger $\mathrm{F} 12$ at $32{ }^{\circ} \mathrm{C}$ and $\mathrm{pH} 6.0$. (a) Time-course curves for accumulated $\mathrm{CO}_{2}$ (left-hand y-axis) and $\beta$-mannanase activity (right-hand y-axis); (b) correlation curve; (c) logistic model fitting.

According to Viccini et al. [38], who fitted kinetic models to a range of experimental results for microbial growth under SSF available in the literature, the logistic model provided a good fit to the results of most of the studies considered. Despite its mathematical simplicity, the logistic model can provide an adequate approximation of the complete growth curve, using a single equation, allowing visualization of the lag, fast growth, and stationary phases. The logistic model Equation (2) is an unstructured empirical model based on experimental observations:

$$
\frac{\mathrm{db}}{\mathrm{dt}}=\mu \cdot \mathrm{b}\left(1-\frac{\mathrm{b}}{\mathrm{b}_{\mathrm{m}}}\right)
$$

where $b$ is the fraction of microbial biomass in the fermented material, $b_{m}$ is its maximum value, and $\mu$ is the specific growth rate. The initial condition adopted to solve Equation (2) was $b=b_{0}$ (the fraction of biomass inoculated at the beginning of the process) at $t=0$. The integrated form of the logistic model is given by:

$$
\mathrm{b}=\frac{\mathrm{b}_{\mathrm{m}}}{1+\left(\frac{\mathrm{b}_{\mathrm{m}}}{\mathrm{b}_{0}}-1\right) \cdot \mathrm{e}^{-\mu \mathrm{t}}}
$$

When all conditions are optimal for growth, $\mu=\mu_{\max }$ (maximum specific growth rate). Fitting Equation (3) to the full curve of the experimental data for the accumulated $\mathrm{CO}_{2}$ concentration resulted in $\mu_{\max }=0.075( \pm 0.004) \mathrm{h}^{-1}\left(\mathrm{R}^{2}=0.992\right.$, Figure 3c) for the bioprocess studied here. It should be noted that this parameter is specific for each combination of microorganism, substrate, and product, hence requiring specific experimental measurements of growth in the system of interest.

Mathematical modeling is a valuable tool for guiding the design, operation, and scale-up of SSF bioreactors, so the value of $\mu_{\max }$ was used as an input for further simulation studies of the bioprocess studied here. Since metabolic heat generation is directly proportional to fungal growth, growth kinetics sub-models are commonly coupled with heat and mass transfer balance equations. The kinetics sub-models are usually empirical relations (in which $\mu_{\max }$ appears as a parameter) that take account of 
the effects of parameters such as temperature and moisture content on microbial growth (expressed by the actual $\mu$ value) and, consequently, on the yields of growth-related enzymes [39-43].

\subsection{Thermostability and Optimum Temperature and $p H$ of $\beta$-Mannanase}

Thermostability can be defined as the activity retained after heating an enzyme extract at a selected temperature for a prolonged period of time [44]. After $24 \mathrm{~h}$ at $50{ }^{\circ} \mathrm{C}$, the $\beta$-mannanase still had $87 \%$ of its original activity (Figure 4). After $12 \mathrm{~h}$ exposure at $50{ }^{\circ} \mathrm{C}$, the enzyme retained $95 \%$ of its activity, while $80 \%$ was retained after $12 \mathrm{~h}$ at $60^{\circ} \mathrm{C}$. Soni et al. [45] produced $\beta$-mannanase using A. terreus FBCC 1369 under SSF, with coconut pulp flour as substrate, and evaluated the stability of the enzyme at $50,60,70$, and $80{ }^{\circ} \mathrm{C}$, during $60 \mathrm{~h}$. After $24 \mathrm{~h}$ at $50^{\circ} \mathrm{C}$, the enzymatic extract had lost more than $10 \%$ of its activity, similar to the present findings. However, at temperatures from 60 to $80{ }^{\circ} \mathrm{C}$, the extract lost $40 \%$ or more of its activity after $24 \mathrm{~h}$. In the present work, around $80 \%$ of the $\beta$-mannanase activity was still retained after $24 \mathrm{~h}$ at $60^{\circ} \mathrm{C}$, showing that the enzyme produced under the conditions employed here was quite stable.

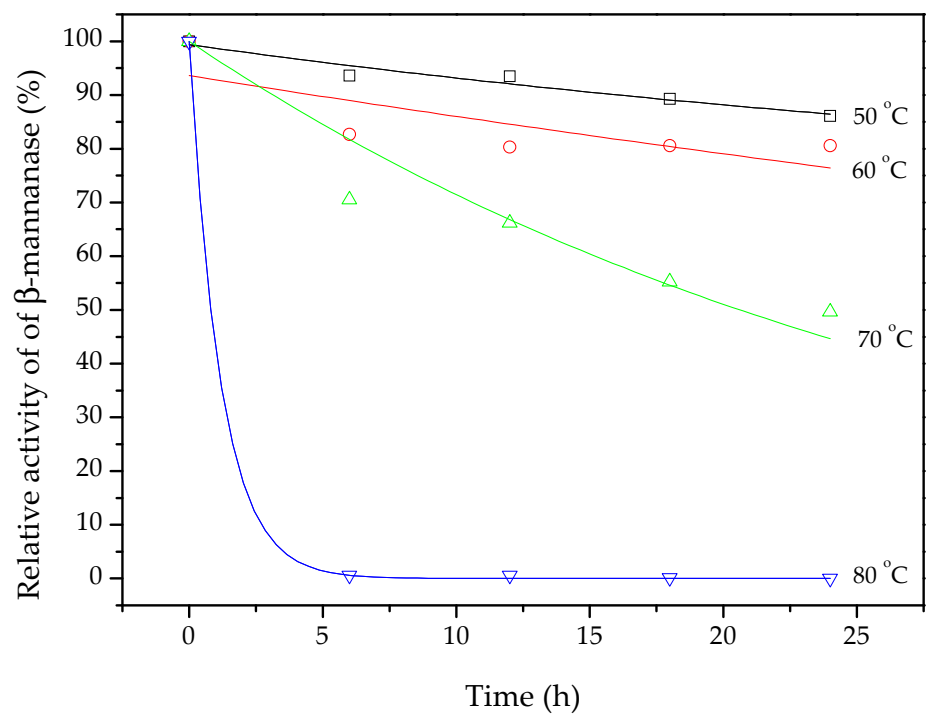

Figure 4. Thermostability of $\beta$-mannanase during $24 \mathrm{~h}$ at $50,60,70$, and $80{ }^{\circ} \mathrm{C}$. The symbols are the experimental data and the lines are exponential decay curve fits.

Since the amount of active enzyme can decline considerably following prolonged exposure to high temperatures, in many industrial applications the kinetics of enzyme deactivation can be as important as the kinetics of the reaction itself [46]. The simplest model of enzyme deactivation expresses the active enzyme concentration as a function of time, considering exponential decay (first order kinetics):

$$
E_{a}=E_{a 0} \cdot e^{-k_{d} \cdot t}
$$

where $\mathrm{Ea}$ is the active enzyme concentration, equal to $\mathrm{Ea}_{0}$ at time ( $\mathrm{t}$ ) zero, and $\mathrm{k}_{\mathrm{d}}$ is the deactivation rate constant. According to Equation (4), the concentration of active enzyme (and consequently the enzyme activity) decreases exponentially with time.

The strong dependence of the rate of enzyme deactivation on the temperature can usually be satisfactorily described using the Arrhenius equation:

$$
k_{d}=A \cdot e^{\left(\frac{-E_{d}}{R g}\right)}
$$


where $\mathrm{A}$ is the Arrhenius constant (or frequency factor), $\mathrm{E}_{\mathrm{d}}$ is the activation energy for enzyme deactivation, $\mathrm{R}_{\mathrm{g}}$ is the ideal gas constant $\left(8.3145 \mathrm{~J} \mathrm{~mol}^{-1} \mathrm{~K}^{-1}\right)$, and $\mathrm{T}$ is the absolute temperature. According to Equation (5), as $\mathrm{T}$ increases, the rate of enzyme deactivation increases exponentially.

The experimental data for the relative $\beta$-mannanase activity $\left(\mathrm{Ea} / \mathrm{Ea}_{0}, \%\right)$ retained during $24 \mathrm{~h}$ at $50,60,70$, and $80^{\circ} \mathrm{C}$ were fitted using exponential decay curves (continuous lines in Figure 4). The model fit was only unsatisfactory for the data obtained at $60{ }^{\circ} \mathrm{C}\left(\mathrm{R}^{2}=0.39\right)$. The values of $\mathrm{k}_{\mathrm{d}}$ and $\mathrm{R}^{2}$ obtained for the different temperatures are presented in Table 4. In addition, Equation (5) was fitted to the data of $k_{d}$ as a function of temperature (in Kelvin). The Arrhenius model parameter values are shown in Table 4.

Table 4. Exponential decay and Arrhenius parameters for $\beta$-mannanase deactivation.

\begin{tabular}{ccc}
\hline \multirow{2}{*}{ Temperature $\left({ }^{\circ} \mathbf{C}\right)$} & \multicolumn{2}{c}{ Exponential Decay } \\
\cline { 2 - 3 } & $\mathbf{k}_{\mathbf{d}} \mathbf{~ ( h}^{\mathbf{- 1}} \mathbf{~}$ & $\mathbf{R}^{\mathbf{2}}$ \\
\hline 50 & 0.006 & 0.93 \\
60 & 0.012 & 0.39 \\
70 & 0.033 & 0.90 \\
80 & 0.833 & 0.99 \\
\hline \multicolumn{3}{c}{ Arrhenius Parameters } \\
\hline Frequency factor, A $\left(\mathrm{h}^{-1}\right)$ & \multicolumn{2}{c}{$1.8 \times 10^{21}$} \\
$\mathrm{E}_{\mathrm{d}}\left(\mathrm{kJ} \mathrm{mol}^{-1}\right)$ & \multicolumn{2}{c}{147} \\
$\mathrm{R}^{2}$ & \multicolumn{2}{c}{0.85} \\
\hline
\end{tabular}

The deactivation energy for the $\beta$-mannanase was slightly lower, but of the same order of magnitude, compared to the usual range for many enzymes (170-400 kJ/mol) [47], so the Arrhenius model fitting confirmed the thermostability of the enzymatic extract produced in the present work. According to the kd values, a temperature increase of $10^{\circ} \mathrm{C}$, from 50 to $60{ }^{\circ} \mathrm{C}$, doubled the rate of enzyme deactivation, while an increase from 70 to $80^{\circ} \mathrm{C}$ increased the rate of deactivation 25 -fold. Hence, it is clear that temperature has a critical effect on enzyme kinetics, so knowledge of the deactivation rate constant, as well as the Arrhenius model parameters, is essential in the design of successful applications for enzymes.

The effects of $\mathrm{pH}$ and temperature on the activity of the $\beta$-mannanase present in the enzyme complex produced by the filamentous fungus $A$. niger F12 grown on coffee waste and wheat bran, under SSF, were evaluated using statistical design of experiments and response surface methodology analyses. Table 5 presents the results of the full factorial design for $\beta$-mannanase activity under the different conditions of temperature and $\mathrm{pH}$ evaluated. Table 6 shows the coefficients of the mathematical model and the statistical parameters.

Table 5. Experimental conditions and results of the central composite rotatable design for the activity of $\beta$-mannanase produced by A. niger F12 in a column-type bioreactor at $32{ }^{\circ} \mathrm{C}$ and $\mathrm{pH} 6.0$, with addition of $8 \mathrm{~mL}$ of Mandels medium.

\begin{tabular}{|c|c|c|c|c|c|}
\hline Run & $X_{1}^{a}$ & $X_{2}^{b}$ & $\beta$-Mannanase Activity (UI/g) ${ }^{c}$ & $\beta$-Mannanase Predicted $(\mathrm{UI} / \mathrm{g})^{\mathrm{d}}$ & Relative Error (\%) ${ }^{e}$ \\
\hline 1 & $-1(50)$ & $-1(4.0)$ & 60.55 & 61.25 & -1.15 \\
\hline 2 & $1(80)$ & $-1(4.0)$ & 70.97 & 80.1 & -12.87 \\
\hline 3 & $-1(50)$ & $1(6.0)$ & 48.49 & 47.31 & 2.44 \\
\hline 4 & $1(80)$ & $1(6.0)$ & 59.12 & 66.16 & -11.9 \\
\hline 5 & $-1.41(43.8)$ & $0(5.0)$ & 41.99 & 43.74 & -4.17 \\
\hline 6 & $1.41(86.8)$ & $0(5.0)$ & 80.38 & 70.38 & 12.44 \\
\hline 7 & $0(65)$ & $-1.41(3.59)$ & 85.72 & 80.37 & 6.25 \\
\hline 8 & $0(65)$ & $1.41(6.41)$ & 63.25 & 60.71 & 4.01 \\
\hline 9 & $0(65)$ & $0(5.0)$ & 94.92 & 94.6 & 0.33 \\
\hline 10 & $0(65)$ & $0(5.0)$ & 95.29 & 94.6 & 0.72 \\
\hline 11 & $0(65)$ & $0(5.0)$ & 93.51 & 94.6 & -1.17 \\
\hline
\end{tabular}


Table 6. Coefficient values (for coded variables) and statistical analysis for $\beta$-mannanase.

\begin{tabular}{|c|c|c|}
\hline Source of Variation & Coefficient & $p$-Value \\
\hline Mean & 94.6 & 0.0000 * \\
\hline Temperature $\left(\mathrm{L}^{\mathrm{a}}\right)$ & 9.43 & $0.0155^{*}$ \\
\hline Temperature $\left(\mathrm{Q}^{\mathrm{b}}\right)$ & -18.79 & 0.0018 * \\
\hline $\mathrm{pH}(\mathrm{L})$ & -6.97 & 0.0446 * \\
\hline $\mathrm{pH}(\mathrm{Q})$ & -12.1 & 0.0117 * \\
\hline Temperature $\times \mathrm{pH}$ & 0.05 & 0.9891 \\
\hline $\mathrm{R}^{2}$ & 0.925 & \\
\hline $\mathrm{F}_{\text {calculated }}$ & 18.4 & \\
\hline $\mathrm{F}_{\text {calculated }} / \mathrm{F}_{\text {listed }}$ & 4.06 & \\
\hline
\end{tabular}

The analysis of variance (ANOVA) for $\beta$-mannanase showed a correlation coefficient $\left(\mathrm{R}^{2}\right)$ of 0.925 and $\mathrm{F}_{\text {calc }} 4.06$ times higher than the tabulated $\mathrm{F}$ value (95\% confidence level). Hence, the statistical indexes were satisfactory for the prediction of the model used to describe the response surface plot of the enzyme activity as a function of $\mathrm{pH}$ and temperature (Figure 5). Equation (6) shows the quadratic model of the real $\beta$-mannanase activity as a function of $\mathrm{pH}$ and temperature:

$$
\mathrm{Y}=-566.818+11.486 \cdot \mathrm{X}_{1}-0.08352 \cdot \mathrm{X}_{1}^{2}+114.05 \cdot \mathrm{X}_{2}-12.102 \cdot \mathrm{X}_{2}^{2}
$$

where $X_{1}$ and $X_{2}$ are the uncoded values of temperature and $\mathrm{pH}$, respectively. The non-significant term (synergistic effect between temperature and $\mathrm{pH}$ ) was incorporated into the residuals for the ANOVA analysis.

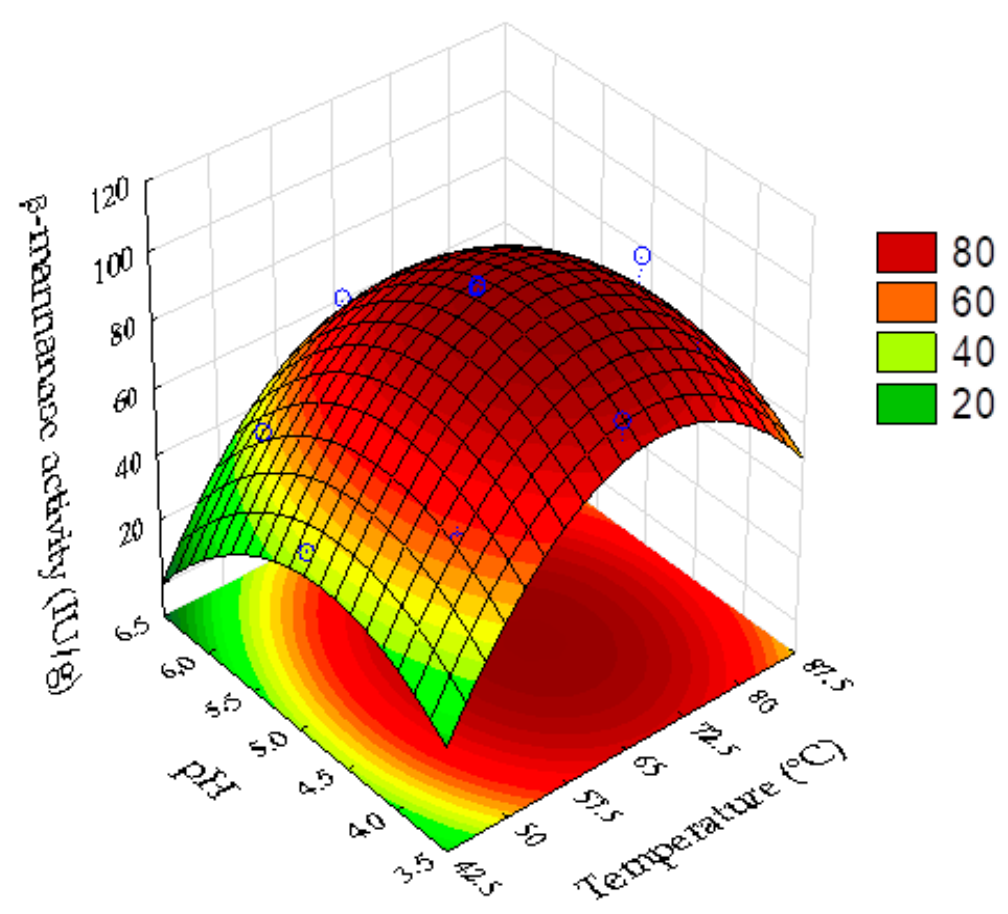

Figure 5. 3D response surface plot for the activity of $\beta$-mannanase, considering the effects of the variables $\mathrm{pH}$ and temperature.

The optimum temperature range for $\beta$-mannanase activity was between approximately 60 and $75{ }^{\circ} \mathrm{C}$ (Figure 5). The optimum $\mathrm{pH}$ range was between approximately 4.1 and 5.3. The best enzyme activity was at $\mathrm{pH} 4.8$ and temperature of $69^{\circ} \mathrm{C}$. Under the optimal condition, the model predicted a $\beta$-mannanase activity of $96.7 \mathrm{UI} / \mathrm{g}$. The model was successfully validated by experimental 
determination of the $\beta$-mannanase activity under the optimum point conditions, with a value of $96.4 \pm$ $0.8 \mathrm{UI} / g$ obtained.

\subsection{Enzymatic Hydrolysis of Coffee Residue}

In order to determine the best conditions for enzymatic hydrolysis using the crude extract produced by $A$. niger F12, solids loadings of 5, 10, and $20 \%$ were studied, aiming at maximizing the release of reducing sugars from the coffee waste. The results showed that the release of reducing sugars from the hydrolyzed solids increased linearly up to a loading of $20 \%$. It is important to use high concentrations of solids, in order to obtain high concentrations of products. However, high solids concentrations can hinder agitation and mass transfer, leading to process losses. In this case, a $20 \%$ solids loading was chosen, since it provided a reducing sugars concentration of approximately $9 \mathrm{~g} / \mathrm{L}$ when hydrolyzed with the crude extract (CE).

The enzymatic extract produced by SSF was also used in combination with the commercial Cellic $\mathrm{CTec} 3$ enzymatic cocktail at $5 \mathrm{FPU} / \mathrm{g}$, for the purpose of comparison. The combination of the crude extract with the commercial enzymes resulted in a $56 \%$ increase in hydrolysis, compared to the reaction using only the crude extract (Figure 6). The addition of an extraction step $15 \mathrm{~min}$ after the enzymatic hydrolysis did not significantly increase the release of reducing sugars. The results indicated the potential for further studies of enzyme production by SSF with coffee waste and the use of these enzymes in enzymatic hydrolysis applications in the soluble coffee industry.

Baraldi et al. [5] performed enzymatic hydrolysis with the fine extraction residue, using a commercial enzyme mixture for hydrolysis in a micro-reactor at $50{ }^{\circ} \mathrm{C}$ and $\mathrm{pH}$ 5.0. The time profile of reducing sugars release was very similar to that obtained here (data not shown). At $71 \mathrm{~h}$ of hydrolysis, Baraldi et al. [5] obtained approximately $9 \mathrm{~g} / \mathrm{L}$ of reducing sugars in hydrolysis using a solids loading of $10 \%$, with release of nearly $70 \%$ of the reducing sugars after around $25 \mathrm{~h}$ of reaction. In this work, $13.6 \pm 0.4 \mathrm{~g} / \mathrm{L}$ of reducing sugars was released after $72 \mathrm{~h}$ of hydrolysis, when a solids loading of $20 \%$ was used. After $24 \mathrm{~h}$ of reaction, the release of the reducing sugars reached around $70 \%$, showing the potential of the enzyme cocktail produced in this study for hydrolyzing coffee polysaccharides, despite being in the form of an unpurified crude extract.

In a recent study of the environmental impacts related to the recovery of cellulase produced in SSF with coffee husks [48], comprising evaluation of the fermentation, extraction, and purification stages of the process, it was observed that the main environmental impact was related to the high energy consumption in the downstream steps after fermentation, especially in the operations for enzyme purification. In the present work, the results showed that the enzymes produced by SSF using coffee waste as substrate were able to hydrolyze coffee polysaccharides, despite the fact that the enzymes were in the form of a crude extract. Although further studies should be performed concerning the concentration and isolation of enzymes, together with evaluation of their specificities, the above evidence suggests that the $\beta$-mannanase enzymatic extract produced here from soluble coffee processing waste may be promising for applications in the soluble coffee industry. 


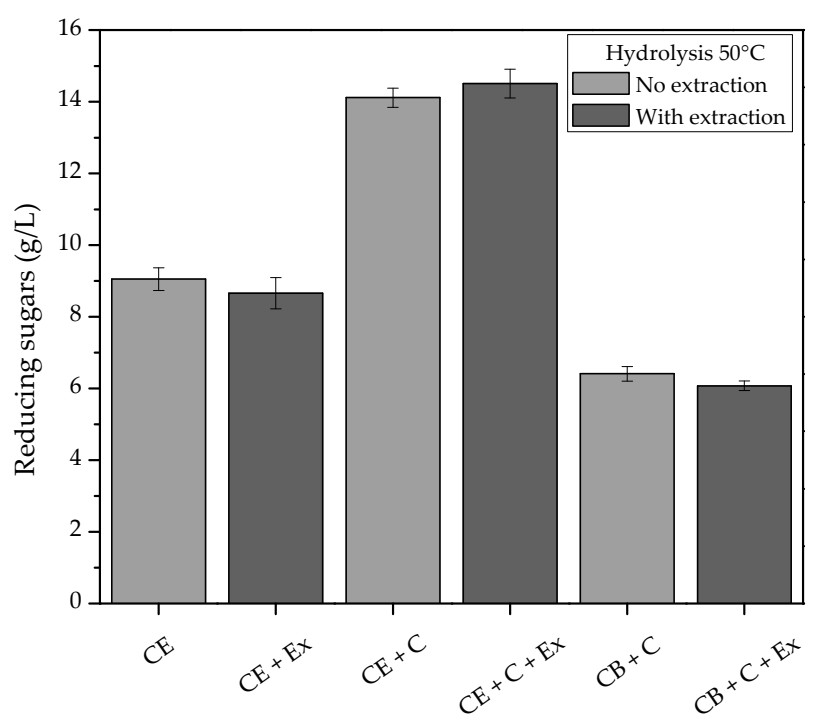

(a)

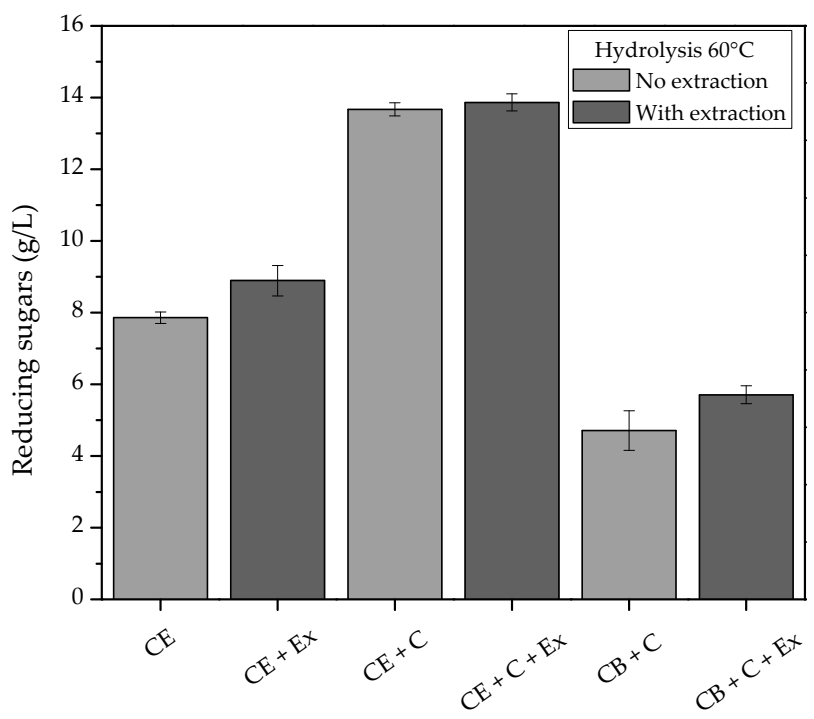

(b)

Figure 6. Concentrations of reducing sugars released from coffee residue using the crude enzyme extract produced here, with and without a commercial enzymatic cocktail, at (a) $50{ }^{\circ} \mathrm{C}$ and (b) $60{ }^{\circ} \mathrm{C}$. Hydrolysis conditions: $30 \mathrm{rpm}$ for $24 \mathrm{~h}$ at $20 \%(w / v)$ solids loading, with or without a thermal extraction period. CE: crude extract (enzymes produced in this work); Ex: 15 min extraction; C: Cellic CTec3 (5 FPU/g); CB: 50 mM sodium citrate buffer ( $\mathrm{pH}$ 5.3).

\section{Conclusions}

The findings of this work demonstrated the significance and potential of utilization of coffee residue, contributing to the development of innovative techniques to make better use of agricultural and industrial wastes. The production of $\beta$-mannanase was optimized using coffee waste and wheat bran $(1: 1, w / w)$ in the column bioreactor with cultivation of $A$. niger F12 under SSF. The coffee waste was important to favor the production of this enzyme, while the wheat bran was a good substrate to support the initial fungal growth. Under the optimal process conditions (considering temperature, $\mathrm{pH}$, and moisture content), the crude enzymatic extract was highly effective in hydrolyzing coffee polysaccharides $(14 \mathrm{~g} / \mathrm{L})$. Improvement of hydrolysis by the addition of a commercial cellulolytic 
enzyme cocktail highlighted the importance of the synergistic action of the enzymes. This work proposes a low-cost medium formulation that could be of industrial value, since $\beta$-mannanases have potential applications in the production of soluble coffee and in other food industries, as well as in animal feed, bio-bleaching of paper and pulps, and in the detergent industry, among others.

Author Contributions: Conceptualization, C.P.F., I.J.B., C.S.F.; methodology C.P.F., I.J.B., F.P.C., C.S.F.; validation, C.P.F.; formal analysis, C.P.F., F.P.C.; investigation, C.P.F.; writing-original draft preparation, C.P.F.; writing-review and editing, I.J.B., F.P.C., C.S.F.; supervision, C.S.F.; funding acquisition, C.S.F. All authors have read and agreed to the published version of the manuscript.

Funding: This research was funded by the São Paulo State Research Foundation (FAPESP, grant numbers 2016/10636-8 and 2018/00996-2), Coordination for the Improvement of Higher Education Personnel (CAPES-Finance Code 001), and the Brazilian National Council for Scientific and Technological Development (CNPq).

Acknowledgments: The authors would like to thank Embrapa, CNPq, CAPES, and FAPESP (all from Brazil) for their financial support.

Conflicts of Interest: The authors declare no conflicts of interest.

\section{References}

1. International Coffee Organization. Available online: www.ico.org (accessed on 22 November 2019).

2. Diaz-Rubio, M.E.; Saura-Calixto, F. Dietary fiber in brewed coffee. J. Agric. Food Chem. 2007, 55, $1999-2003$. [CrossRef]

3. Nunes, F.M.; Coimbra, M.A. Chemical characterization of the high molecular weight material extracted with hot water from green and roasted robusta coffee as affected by the degree of roast. J. Agric. Food Chem. 2002, 50, 7046-7052. [CrossRef] [PubMed]

4. Redgwell, R.J.; Trovato, V.; Curti, D.; Fischer, M. Effect of roasting on degradation and structural features of polysaccharides in Arabica coffee beans. Carbohydr. Res. 2002, 337, 421-431. [CrossRef]

5. Baraldi, I.J.; Giordano, R.L.C.; Zangirolami, T.C. Enzymatic hydrolysis as an environmentally friendly process compared to thermal hydrolysis for instant coffee production. Braz. J. Chem. Eng. 2016, 33, 763-771. [CrossRef]

6. De Maria, C.A.B.; Trugo, L.C.; Neto, F.R.A.; Moreira, R.F.A. Arabinogalactan as a potential furfural precursor in roasted coffee. Int. J. Food Sci. Technol. 1994, 29, 559-562. [CrossRef]

7. Soni, H.; Kango, N. Microbial Mannanases: Properties and Applications. In Advances in Enzyme Biotechnology; Shukla, P., Pletschke, B., Eds.; Springer: New Delhi, India, 2013; pp. 41-56.

8. Ozturk, B.; Cekmecelioglu, D.; Ogel, Z.B. Optimal conditions for enhanced beta-mannanase production by recombinant Aspergillus sojae. J. Mol. Catal. B Enzym. 2010, 64, 135-139. [CrossRef]

9. Abdeshahian, P.; Samat, N.; Hamid, A.A.; Yusoff, W.M.W. Utilization of palm kernel cake for production of beta-mannanase by Aspergillus niger FTCC 5003 in solid substrate fermentation using an aerated column bioreactor. J. Ind. Microbiol. Biotechnol. 2010, 37, 103-109. [CrossRef] [PubMed]

10. Maijala, P.; Kango, N.; Szijarto, N.; Viikari, L. Characterization of hemicellulases from thermophilic fungi. Antonie Van Leeuwenhoek. 2012, 101, 905-917. [CrossRef] [PubMed]

11. Yoo, H.Y.; Pradeep, G.C.; Lee, S.K.; Park, D.H.; Cho, S.S.; Choi, Y.H.; Yoo, J.C.; Kim, S.W. Understanding beta-mannanase from Streptomyces sp CS147 and its potential application in lignocellulose based biorefining. Biotechnol. J. 2015, 10, 1894-1902. [CrossRef]

12. Meenakshi, M.; Singh, G.; Bhalla, A.; Hoondal, G.S. Solid-state fermentation and characterization of partially purified thermostable mannanase from Bacillus sp. MG-33. Bioresources 2010, 5, 1689-1701.

13. Mou, H.; Zhou, F.; Jiang, X.; Liu, Z. Production, purification and properties of beta-mannanase from soil bacterium Bacillus circulans M-21. J. Food Biochem. 2011, 35, 1451-1460. [CrossRef]

14. Ge, J.P.; Du, R.P.; Zhao, D.; Song, G.; Jim, M.; Ping, W.X. Bio-chemical characterization of a $\beta$-mannanase from Bacillus licheniformis HDYM-04 isolated from flax water-retting liquid and its decolorization ability of dyes. RSC Adv. 2016, 6, 23612-23621. [CrossRef]

15. Holker, U.; Hofer, M.; Lenz, J. Biotechnological advantages of laboratory-scale solid-state fermentation with fungi. Appl. Microbiol. Biotechnol. 2004, 64, 175-186. [CrossRef] [PubMed] 
16. Singhania, R.R.; Sukumaran, R.K.; Patel, A.K.; Larroche, C.; Pandey, A. Advancement and comparative profiles in the production technologies using solid-state and submerged fermentation for microbial cellulases. Enzyme Microb. Technol. 2010, 46, 541-549. [CrossRef]

17. Farinas, C.S. Developments in solid-state fermentation for the production of biomass-degrading enzymes for the bioenergy sector. Renew. Sustain. Energy Rev. 2015, 52, 179-188. [CrossRef]

18. Casciatori, F.P.; Casciatori-Frassatto, P.A. Enzymes for the Biochemical Route of Second-Generation Ethanol: Production by Solid-State Cultivation as a Feasible and Sustainable Alternative. In Bioethanol and Beyond: Advances in Production Process and Future Directions; Brienzo, M., Ed.; Nova Science Publishers: New York, NY, USA, 2018; pp. 285-313.

19. Murthy, P.S.; Naidu, M.M. Sustainable management of coffee industry by-products and value addition-A review. Resour. Conserv. Recycl. 2012, 66, 45-58. [CrossRef]

20. Cerda, A.; Mejías, L.; Gea, T.; Sánchez, A. Cellulase and xylanase production at pilot scale by solid-state fermentation from coffee husk using specialized consortia: The consistency of the process and the microbial communities involved. Bioresour. Technol. 2017, 243, 1059-1068. [CrossRef]

21. Kourmentza, C.; Economou, C.N.; Tsafrakidou, R.; Kornaros, M. Spent coffee grounds make much more than waste: Exploring recent advances and future exploitation strategies for the valorization of an emerging food waste stream. J. Clean. Prod. 2018, 172, 980-992. [CrossRef]

22. Kovalcik, A.; Obruca, S.; Marova, I. Valorization of spent coffee grounds: A review. Food Bioprod. Process. 2018, 110, 104-119. [CrossRef]

23. McNutt, J.; He, Q. Spent coffee grounds: A review on current utilization. J. Ind. Eng. Chem. 2019, 71, 78-88. [CrossRef]

24. Mandels, M.; Stenberg, D. Recent advances in cellulase technology. J. Ferment. Technol. 1976, 54, $267-286$.

25. Durand, A. Bioreactor designs for solid state fermentation. Biochem. Eng. J. 2003, 13, 113-125. [CrossRef]

26. Miller, G.L. Use of dinitrosalicylic acid reagent for determination of reducing sugar. Anal. Chem. 1959, 31, 426-428. [CrossRef]

27. Stalbrand, H.; Siika-Aho, M.; Tenkanen, M.; Viikari, L. Purification and characterization of two $\beta$-mannanases from Trichoderma reesei. J. Biotechnol. 1993, 29, 229-242. [CrossRef]

28. Ghose, T.K. Measurement of cellulase activities. Pure Appl. Chem. 1987, 59, 257-268. [CrossRef]

29. Javed, M.M.; Zahoor, S.; Shafaat, S.; Mehmooda, I.; Gul, A.; Rasheed, H.; Bukhari, S.A.I.; Aftab, M.N.; Ikram-ul-Haq. Wheat bran as a brown gold: Nutritious value and its biotechnological applications. Afr. J. Microbiol. Res. 2012, 6, 724-733.

30. Cavalcante, R.S.; Lima, H.L.S.; Pinto, G.A.S.; Gava, C.A.T.; Rodrigues, S. Effect of moisture on Trichoderma conidia production on corn and wheat bran by solid state fermentation. Food Bioprocess. Technol. 2008, 1, 100-104. [CrossRef]

31. Malathi, S.; Chakraborty, R. Production of alkaline protease by a new Aspergillus flavus isolate under solid-substrate fermentation conditions for use as a depilation agent. Appl. Environ. Microbiol. 1991, 57, 712-716. [CrossRef]

32. Ellaiah, P.; Adinarayana, K.; Bhavani, Y.; Padmaja, P.; Srinivasulu, B. Optimization of process parameters for glucoamylase production under solid state fermentation by a newly isolated Aspergillus species. Process. Biochem. 2002, 38, 615-620. [CrossRef]

33. De Vries, R.P.; Visser, J. Aspergillus enzymes involved in degradation of plant cell wall polysaccharides. Microbiol. Mol. Biol. Rev. 2001, 65, 497. [CrossRef]

34. Ferreira, H.M.; Filho, E.X.F. Purification and characterization of a $\beta$-mannanase from Trichoderma harzianum strain T4. Carbohydr. Polym. 2004, 57, 23-29. [CrossRef]

35. Arora, S.; Rani, R.; Ghosh, S. Bioreactors in solid state fermentation technology: Design, applications and engineering aspects. J. Biotechnol. 2018, 269, 16-34. [CrossRef] [PubMed]

36. Palomino, L.R.; Biasetto, C.R.; Araujo, A.R.; Bianchi, V.L.D. Enhanced extraction of phenolic compounds from coffee industry's residues through solid state fermentation by Penicillium purpurogenum. Food Sci. Technol. 2015, 35, 704-711. [CrossRef]

37. Farinas, C.S.; Vitcosque, G.L.; Fonseca, R.F.; Bertucci Neto, V.; Couri, S. Modeling the effects of solid-state fermentation operating conditions on endoglucanase production using an instrumented bioreactor. Ind. Crop. Prod. 2011, 34, 1186-1192. [CrossRef] 
38. Viccini, G.; Mitchell, D.A.; Boit, S.D.; Gern, J.C.; da Rosa, A.S.; Costa, R.M.; Dalsenter, F.D.H.; von Meien, O.F.; Krieger, N. Analysis of growth kinetic profiles in solid-state fermentation. Food Technol. Biotechnol. 2001, 39, 271-294.

39. Glenn, D.R.; Rogers, P.L. A solid substrate process for an animal feed product: Studies on fungal strain improvement. Aust. J. Biotechnol. 1988, 2, 50-57.

40. Saucedo-Castañeda, G.; Gutiérrez-Rojas, M.; Bacquet, G.; Raimbault, M.; Viniegra-González, G. Heat transfer simulation in solid substrate fermentation. Biotechnol. Bioeng. 1990, 35, 802-808. [CrossRef]

41. Sangsurasak, P.; Mitchell, D.A. The investigation of transient multidimensional heat transfer in solid state fermentation. Chem. Eng. J. 1995, 60, 199-204. [CrossRef]

42. von Meien, O.F.; Mitchell, D.A. A two-phase model for water and heat transfer within an intermittently-mixed solid-state fermentation bioreactor with forced aeration. Biotechnol. Bioeng. 2002, 79, 416-428. [CrossRef]

43. Casciatori, F.P.; Bück, A.; Thoméo, J.C.; Tsotsas, E. Two-phase and two-dimensional model describing heat and water transfer during solid-state fermentation within a packed-bed bioreactor. Chem. Eng. J. 2016, 287, 103-116. [CrossRef]

44. Farinas, C.S.; Loyo, M.M.; Baraldo Junior, A.; Tardioli, W.; Bertucci Neto, V.; Couri, S. Finding stable cellulase and xylanase: Evaluation of the synergistic effect of $\mathrm{pH}$ and temperature. New Biotechnol. 2010, 27, 810-815. [CrossRef] [PubMed]

45. Soni, H.; Rawat, H.K.; Pletschke, B.I.; Kango, N. Purification and characterization of beta-mannanase from Aspergillus terreus and its applicability in depolymerization of mannans and saccharification of lignocellulosic biomass. 3 Biotech 2016, 6, 11. [CrossRef] [PubMed]

46. Doran, P.M. Bioprocess Engineering Principles, 1st ed.; Elsevier: Amsterdam, The Netherlands, 1995.

47. Sizer, I.W. Effects of temperature on enzyme kinetics. Adv. Enzym. 1943, 3, 35-62.

48. Catalán, E.; Komilis, D.; Sánchez, A. Environmental impact of cellulase production from coffee husks by solid-state fermentation: A life-cycle assessment. J. Clean. Prod. 2019, 233, 954-962. [CrossRef]

(C) 2020 by the authors. Licensee MDPI, Basel, Switzerland. This article is an open access article distributed under the terms and conditions of the Creative Commons Attribution (CC BY) license (http://creativecommons.org/licenses/by/4.0/). 